\title{
Effects of Agroculture-English Integrate Education Program on College Students' Agro-entrepreneurial intention - With a focus on G University Case
}

\author{
Yong-Wook Shin ${ }^{1,2}$ * \\ ${ }^{1}$ Department of Agronomy \& Medicinal Plant Resources, Gyeongnam National University of Science and Technology, Jinju 52725, South \\ Korea \\ ${ }^{2}$ International Garden Institute, Gyeongnam National University of Science and Technology, Jinju 52725, South Korea
}

\begin{abstract}
The Purpose of this study was to develop integrate education program and method for college students, We run English education program and Farming activities half and half; such as endangered plant surveys, gardening, mulching, visiting university attached farm, and local tourism farm for 4 weeks. The results of this study are as follows: First, Agro-entrepreneurial intention is more likely to be found in the English \& Farming activity participants, and Male students than English\&culture activity participants, and female students respectively. In the context of the effectiveness of the English Learning Program, students with poor English learning usefulness have strong desire to build up their own business, whereas those with higher English learning suitability are more likely to have a strong desire to start farming. In terms of entrepreneurship, the tendency toward entrepreneurship, risk sensitivity. and in terms of self - efficacy, The bigger the confidence, the greater the will to start an agricultural business. The results supported that The English education program with farming activities has a significant and positive influence on Agro-entrepreneurial intention in college students.
\end{abstract}

Keywords: agro-entrepreneurial intention, career awareness, english learning program, integrate education

\section{Introduction}

As youth employment continues to be deteriorated, more and more college students have come to take a leave of absence or defer graduation. In fact, there has been a constant increase in the time required for Korean college students from admission to graduation in the last 10 years (Yi, 2016). In many cases they go abroad for language studies during their leave of absence. $15.4 \%$ of 4-year college graduates have experience studying foreign language abroad, many of the destinations being English-speaking countries. It was discovered that people who have studied abroad for language studies are more likely to succeed in getting a job when all other conditions are the same (24.3\%), received relatively higher wages (7\%), spent less time seeking a job (12.8\%), and had longer term of service (8.8\%) (Park, 2009). Accordingly, many colleges in Korea provide financial and administrative support for short-term overseas training of students by

This paper received sabbatical funding from the Gyeongnam National University of Science and Technology accounting system in 2015.

Received: June 15, 2017, Revised: June 30, 2017, Accepted: August 3, 2017

*Comesponding author: ywsynn@gntech.ac.kr 
implementing more and more globalization programs, and encourage participation in internships and language studies abroad without taking a leave of absence. In fact, after going on a short-term overseas language training, learners generally gained confidence and lost fear about English in terms of learning methods, and were motivated to have more interest in learning, which shows that such changes in attitude and motive led to an increase in the achievement level of language learning (Yoon, 2011).

In addition to motivation for English learning, students can actually promote a broader scope of self-growth and reestablishment of identity beyond language (Yang, 2015). Global internships also allow students to expand their perceptive horizons through participation, clarify their career goals by enhancing interaction skills with people who have different cultural backgrounds, and increase the possibility of overseas employment by increasing the ability to adapt to global culture (Noguchi et al., 2008). Development of programs to motivate students for English learning through short-term overseas job experience and clarify their career goals is requested in colleges. Through such career exploration activities, students can comprehend the criteria for career choices by developing and understanding their potential capabilities and roles as a member of the society, which affects their career awareness to have knowledge about occupation (Kim, 2006).

Meanwhile, emotional and social effects of students by horticultural integrated education have been constantly proved in Europe and Japan as well as the United States beyond just part of vocational training. In the case of US, such education is led by the external training program of Land Grant Univ. (Jeong et al., 2010). There are five advantages of integrated education using horticulture as the medium: lifelong learning is possible, it can be combined with various curriculums, it uses living organisms as a medium, adequate convergence is possible, and classes can be held actively in a beautiful natural environment (Lynn,1983). The JMG (Junior Master Gardener) program in the US offers an integrated program that provides not only knowledge about horticulture but also various courses and language training sessions in addition to nature, environment and science through interesting eco-friendly activities. It links to related subjects such as social studies, art and environment within the sub-topics related to horticultural activities, aiming for horizontal as well as vertical connection to extensive age groups by adjusting difficulty levels and learning topics without the boundaries of curriculum (Kwak et al., 2012). In particular, the following is an example of a program that connects language training to garden activities. A study was conducted on Grade 4 students at Miller Elementary School in West Chester County, New York, in the spring semester of 2009, carrying out English literacy education for ESL students in connection with garden activities. The result showed that, by running an ESL course through garden activities, students proficient in English promote confidence in communication by writing poetry and essays describing nature or talking in English, while students less proficient in English promote confidence by drawing their activities in the garden or writing journals (DuRivage, 2011). In addition, the US also expanded and developed the scope of education to agricultural science education and agricultural literacy education, breaking free from the one-sided agricultural vocation education since the 1980s. In particular, since 1981, the US federal government has been running the AITC (Agriculture in the Classroom) program, officially supporting students from kindergarten to high school, carrying out general agricultural education (Bang, 2015) and managing agricultural and horticultural activities as an integrated course. Agricultural education through integrated education carried out by each level of educational institutions including higher education rather produces a greater synergy when integrated with the English subject (Chung, 2004). Thus, G University in Gyeongnam implemented a four-week program that integrated English learning and crop cultivation experience for agriculture department students at G University in the US that is its sister college. The program consisted of English learning, advanced recycling agriculture and visit to tourism sites for agriculture, and improvement of agricultural career awareness. G University in Korea selected students from the departments of agriculture and horticulture, while G University in the US had the local program run by the Center for Island Sustainability (CIS). The CIS is an intramural center affiliated to the university established in 
2009, which developed island-based sustainable technology to resolve various social issues in environment, economy, society and education, striving to build a new model. Since 2012, the center has been using shredded papers on campus as mulching materials at gardens on campus and affiliated farms, and has been in charge of multidisciplinary approaches to research and education on constant recycling of resources and environmental problems, such as renewable energy, energy-saving architecture, rainwater recycling, sustainable gardens, etc.

Accordingly, this study is conducted to compare the effects of language learning as horticultural integrated education on the learning effects and occupational view by comparing the effects of an English training program combined with agricultural activities in the US with the benefits of a conventional English training program abroad.

\section{Research Method}

\section{Subjects and method}

\section{Subjects}

Two types of overseas language training teams (4 weeks) were sent to G University in the US from January 5 February 1, 2017, which are the winter holidays of 2016. For the program recruiting all college students, there was a language training program that combined English and local cultural experience (cultural activity, 10 students), and for agricultural department students, there was a program that combined English and farming experience (farming activity, 14 students). The hours for English training were the same for both programs, but the cultural activity program involved sports and local cultural activities besides English training, while the farming activity program consisted of investigating endangered plant species in the mountains and rivers, tending gardens, mulching, visiting college-affiliated farms, and visiting local tour farms. Questionnaires were distributed to the two teams, all of which were collected for a survey.

\section{Survey content}

To conduct this study, previous studies were used as a reference in drawing up the items for the questionnaire, which were verified by experts in English literature and statistics and then modified for improvement. The survey items for students about outdoor agricultural activities consisted of overseas language training experience, TOEIC score, interest in agriculture, succession of agriculture, entrepreneurship, self-efficacy, creative personality, agro-entrepreneurial intention, and English learning effects. The terms used in the questionnaire to promote understanding of students were all replaced by terms that can be understood by all of them regardless of their majors. Each item had different choices according to the characteristics, and items assessing satisfaction, awareness and intention were rated on a 5-point Likert scale. The survey was conducted after obtaining approval of the person in charge of the program and explaining the survey method sufficiently. The questionnaire was distributed in each class, which was filled out by the respondents and collected anonymously. The survey was conducted from January 31 to February 10, 2017.

\section{Data processing method}

Data in this study was analyzed using IBM SPSS 21.0.

The distribution of demographic characteristics of the research groups was determined by cross-tabulation analysis, and exploratory factor analysis and Cronbach's Alpha coefficients were measured to test the validity and reliability of the measurement variables. Moreover, since the research groups are small samples under 25 persons, the test of normality of the variables was performed by One-Sample Kolmogorov-Smirnov Test. Accordingly, this study examined the awareness 
difference using the independent samples t-test and Mann-Whitney $U$ test according to the type of English learning.

The demographic characteristics were controlled for agro-entrepreneurial intention, and independent variables include 6th industry entrepreneurship (innovation, initiative, risk sensitivity, collaboration, communication skill, networking capabilities), self-efficacy (self-confidence, self-control, task difficulty), creative personality (curiosity, task commitment, open mind, aesthetic impression), English learning effects (educational interest, confidence of learning, English learning usefulness, English learning suitability), and stepwise regression analysis was conducted. The significance level of all analyses was $\alpha=.05$.

\section{Results and Discussions}

\section{Distribution of demographic characteristics among research subjects}

The distribution of demographic characteristics among research groups is as shown in Table 1.

The farming activity program had all students in the departments related to agriculture, but the cultural activity program had a $50 \%$ distribution. As for TOEIC score, the farming activity program consisted of subjects with low TOEIC scores at 500 points or below, whereas the cultural activity program had more students that got 700 points or above. For the farming activity program, farming activity satisfaction had an average of 4.00 , and the agricultural commerce activity had an

Table 1. Distribution of demographic characteristics among research groups.

\begin{tabular}{|c|c|c|c|c|c|}
\hline & & Farming Activity & Cultural Activity & Total & $\chi^{2}(p)$ \\
\hline \multirow{2}{*}{ Gender } & Man & $5(35.7)$ & $5(50.0)$ & $10(41.7)$ & \multirow{2}{*}{$\begin{array}{c}.490 \\
(.484)\end{array}$} \\
\hline & Woman & $9(64.3)$ & $5(50.0)$ & $14(58.3)$ & \\
\hline \multirow{2}{*}{ Age } & $\leq 24$ & $9(64.3)$ & $8(80.0)$ & $17(70.8)$ & \multirow{2}{*}{$\begin{array}{l}.397^{1)} \\
(.653)\end{array}$} \\
\hline & $\geq 25$ & $5(35.7)$ & $2(20.0)$ & $7(29.2)$ & \\
\hline \multirow{2}{*}{ Major } & College of agricultural sciences & $14(100.0)$ & $5(50.0)$ & $19(79.2)$ & \multirow{2}{*}{$\begin{array}{l}8.842^{* *} \\
(.003)\end{array}$} \\
\hline & the others & - & $5(50.0)$ & $5(20.8)$ & \\
\hline \multirow{2}{*}{ Overseas experience } & Yes & - & $2(20.0)$ & $2(8.3)$ & \multirow{2}{*}{$\begin{array}{l}3.055 \\
(.081)\end{array}$} \\
\hline & No & $14(100.0)$ & $8(80.0)$ & $22(91.7)$ & \\
\hline \multirow{3}{*}{ TOEIC score } & $\leq 500$ & $10(71.4)$ & - & $10(41.7)$ & \multirow{3}{*}{$\begin{array}{c}16.947^{* * *} \\
(.000)\end{array}$} \\
\hline & $500-700$ & $4(28.6)$ & $3(30.0)$ & $7(29.2)$ & \\
\hline & $\geq 700$ & - & $7(70.0)$ & $7(29.2)$ & \\
\hline \multirow{2}{*}{ Family farming } & Yes & - & $1(10.0)$ & $1(4.2)$ & \multirow{2}{*}{$\begin{array}{l}1.461 \\
(.227)\end{array}$} \\
\hline & No & $14(100.0)$ & $9(90.0)$ & $23(95.8)$ & \\
\hline \multirow{2}{*}{ Cultural Activity satisfaction } & Sports Activity & & $3.10 \pm 0.57$ & $3.10 \pm 0.57$ & - \\
\hline & Cultural experience & & $3.50 \pm 1.35$ & $3.50 \pm 1.35$ & - \\
\hline \multirow{2}{*}{ Farming Activity satisfaction } & Farming Activity & $4.00 \pm 0.78$ & & $4.00 \pm 0.78$ & - \\
\hline & Agricultural commerce activity & $3.43 \pm 1.16$ & & $3.43 \pm 1.16$ & - \\
\hline
\end{tabular}

Values are presented number $(\%)$ or mean \pm standard deviation.

${ }^{* *} p<.01 .{ }^{* * *} p<.001$.

${ }^{1)}$ Fisher's Exact Test. 
average of 3.43. For the cultural activity program, sports activity had an average of 3.10, and the local cultural experience had an average of 3.50, proving that farming activity had the highest satisfaction in the farming activity program.

\section{Reliability and validity testing of the questionnaire}

For factor analysis of each variable, the common factors of each questionnaire were extracted, and principal component analysis was conducted for factor extraction, with VARIMAX rotation and eigen value set as 1.0 or above.

The result of exploratory factor analysis on 6th industry entrepreneurship (Kim et al., 2016) showed that 6 factors were extracted from 9 factors presented in the study, explaining $83.989 \%$ of all variables. It was found that for social responsibility, authenticity and conductivity, 6th industry entrepreneurship analyzed among the students was excluded, and 2 items of innovation, 1 item of initiative, 2 items of risk sensitivity, and 3 items of collaboration were excluded. Moreover, as a result of using KMO (Kaiser-MeyerOlkin, 0.7 or higher) and Bartlett's sphericity to verify the validity of factor analysis, it was found that $\mathrm{KMO}=.867$, Bartlett's sphericity $\chi^{2}=2470.961, p=.000$ with significance.

The result of exploratory factor analysis on self-efficacy showed that $74.753 \%$ of all variables were explained. Task

Table 2. The 6th Industry Entrepreneurship Factor Analysis.

\begin{tabular}{|c|c|c|c|c|c|}
\hline & & $\begin{array}{l}\text { Factor } \\
\text { Loading }\end{array}$ & $\begin{array}{l}\text { Eigen } \\
\text { Value }\end{array}$ & $\begin{array}{c}\% \text { of } \\
\text { Variance }\end{array}$ & $\begin{array}{c}\% \text { of Cum. } \\
\text { Variance }\end{array}$ \\
\hline \multirow{3}{*}{ Innovation } & (2) Seeking constant change & .851 & \multirow{3}{*}{4.082} & \multirow{3}{*}{18.557} & \multirow{3}{*}{18.557} \\
\hline & (3) Trying to introduce the latest management techniques & .846 & & & \\
\hline & (4) Trying to use creative marketing methods & .883 & & & \\
\hline \multirow{4}{*}{ Initiative } & (1) Continue to identify market trends & .801 & \multirow{4}{*}{3.663} & \multirow{4}{*}{16.652} & \multirow{4}{*}{35.208} \\
\hline & (2) Identify customer needs & .872 & & & \\
\hline & (3) Quickly identify competitors' movements & .845 & & & \\
\hline & (4) Introducing new services and products & .748 & & & \\
\hline \multirow{3}{*}{ Risk sensitivity } & (1) Responding to environmental changes actively & .783 & \multirow{3}{*}{3.526} & \multirow{3}{*}{16.027} & \multirow{3}{*}{51.235} \\
\hline & (3) Take a reckless challenge to get a chance & .837 & & & \\
\hline & (4) Active efforts to enter new business fields & .840 & & & \\
\hline \multirow{2}{*}{ Collaboration } & (1) Follow and participate in common goals & .896 & \multirow{2}{*}{2.550} & \multirow{2}{*}{11.592} & \multirow{2}{*}{62.827} \\
\hline & (2) Willing to care colleague & .838 & & & \\
\hline \multirow{5}{*}{$\begin{array}{l}\text { Communication } \\
\text { skill }\end{array}$} & (1) Trying to understand from the other's perspective & .799 & \multirow{5}{*}{2.534} & \multirow{5}{*}{11.518} & \multirow{5}{*}{74.344} \\
\hline & (2) Listen courteously others opinion & .795 & & & \\
\hline & (3) Freely give my opinion & .875 & & & \\
\hline & (4) Coordinate opposing views in a variety of ways & .863 & & & \\
\hline & (5) Interested in the others claims and actions & .871 & & & \\
\hline \multirow{5}{*}{$\begin{array}{l}\text { Networking } \\
\text { capabilities }\end{array}$} & (1) Frequently attend seminars and workshops & .729 & \multirow{5}{*}{2.122} & \multirow{5}{*}{9.644} & \multirow{5}{*}{83.989} \\
\hline & (2) Attends association and organizational activities & .799 & & & \\
\hline & (3) Get information from various people & .660 & & & \\
\hline & (4) Frequent contact with business contacts & .889 & & & \\
\hline & (5) Frequent attendance at various social gatherings & .774 & & & \\
\hline
\end{tabular}


difficulty had 2 items excluded. Moreover, as a result of using KMO and Bartlett's sphericity to verify the validity of factor analysis, it was found that $\mathrm{KMO}=.800$, Bartlett's sphericity $\chi^{2}=1191.744, p=.000$ with significance.

The result of exploratory factor analysis on agro-entrepreneurial intention showed that $85.359 \%$ of all variables were explained. As a result of using KMO and Bartlett's sphericity to verify the validity of factor analysis, it was found that $\mathrm{KMO}=.828$, Bartlett's sphericity $\chi^{2}=439.623, p=.000$ with significance.

The result of exploratory factor analysis on creative personality showed that 4 factors were extracted from total 6 factors, explaining $81.112 \%$ of all variables. Independence of judgment and risk taking factors were excluded, and 1 item of aesthetic impression was excluded. Moreover, as a result of using $\mathrm{KMO}$ and Bartlett's sphericity to verify the validity of factor analysis, it was found that $\mathrm{KMO}=.705$, Bartlett's sphericity $\chi^{2}=518.205, p=.000$ with significance.

The result of exploratory factor analysis on English learning effects showed that 4 factors explained $82.873 \%$ of all

Table 3. Self-efficacy Factor Analysis

\begin{tabular}{|c|c|c|c|c|c|}
\hline & & $\begin{array}{l}\text { Factor } \\
\text { Loading }\end{array}$ & $\begin{array}{l}\text { Eigen } \\
\text { Value }\end{array}$ & $\begin{array}{c}\% \text { of } \\
\text { Variance }\end{array}$ & $\begin{array}{c}\% \text { of Cum. } \\
\text { Variance }\end{array}$ \\
\hline \multirow{6}{*}{$\begin{array}{l}\text { Self- } \\
\text { confidence }\end{array}$} & (1) There is a foreboding of failure starting a new job & .806 & \multirow{6}{*}{4.426} & \multirow{6}{*}{27.661} & \multirow{6}{*}{27.661} \\
\hline & (2) Can't do anything because confronted with difficulties. & .822 & & & \\
\hline & (3) In a threatening situation, get stressed excessively & .841 & & & \\
\hline & (4) Can't do anything because of having a big problem. & .822 & & & \\
\hline & (5) People around me seem to excel in everything I do. & .784 & & & \\
\hline & (6) It is afraid can't get out of danger. & .866 & & & \\
\hline \multirow{6}{*}{ Self-control } & (1) Process a work systematically & .604 & \multirow{6}{*}{4.164} & \multirow{6}{*}{26.023} & \multirow{6}{*}{53.685} \\
\hline & (2) Can set up a good plan & .860 & & & \\
\hline & (3) Can predict the cause and progress of work & .922 & & & \\
\hline & (4) Everything is handled right and exact & .871 & & & \\
\hline & (5)Always set goals and identify the progress of the work & .800 & & & \\
\hline & (6) The judgment on the goal is correct. & .708 & & & \\
\hline \multirow{4}{*}{$\begin{array}{l}\text { Task } \\
\text { difficulty }\end{array}$} & (1) The easier things are good to do. & .745 & \multirow{4}{*}{3.371} & \multirow{4}{*}{21.068} & \multirow{4}{*}{74.753} \\
\hline & (3) Prefer hard work rather than easy work & .860 & & & \\
\hline & (4) Even if make mistakes, like hard work. & .820 & & & \\
\hline & (6) If I can choose, I will choose an easier task than a hard one & .822 & & & \\
\hline
\end{tabular}

Table 4. Agro-entrepreneurial intention Factor Analysis.

\begin{tabular}{|c|c|c|c|c|c|}
\hline & & $\begin{array}{l}\text { Factor } \\
\text { Loading }\end{array}$ & $\begin{array}{l}\text { Eigen } \\
\text { Value }\end{array}$ & $\begin{array}{c}\% \text { of } \\
\text { Variance }\end{array}$ & $\begin{array}{c}\% \text { of Cum. } \\
\text { Variance }\end{array}$ \\
\hline \multirow{5}{*}{$\begin{array}{l}\text { Agro- } \\
\text { entrepreneurial } \\
\text { intention }\end{array}$} & (1) There is a firm plan to establish an agricultural business in the near future. & .921 & \multirow{5}{*}{4.268} & \multirow{5}{*}{85.359} & \multirow{5}{*}{85.359} \\
\hline & (2) I want to start an agricultural business even if there are many risks. & .894 & & & \\
\hline & (3) Someday I will have my own agricultural business. & .802 & & & \\
\hline & (4) I will have my own agricultural business in the next 5 years. & .902 & & & \\
\hline & (5) Willing to own or operate an agricultural business. & .806 & & & \\
\hline
\end{tabular}


variables. As a result of using KMO and Bartlett's sphericity to verify the validity of factor analysis, it was found that $\mathrm{KMO}=.756$, Bartlett's sphericity $\chi^{2}=1192.261, p=.000$ with significance.

Inner congruence of the questionnaire was determined through Cronbach's alpha coefficients.

As a result of testing the reliability of the variables, the reliability of 6th industry entrepreneurship was .830 or above,

Table 5. Creative personality Factor Analysis.

\begin{tabular}{|c|c|c|c|c|c|}
\hline & & $\begin{array}{l}\text { Factor } \\
\text { Loading }\end{array}$ & $\begin{array}{l}\text { Eigen } \\
\text { Value }\end{array}$ & $\begin{array}{c}\% \text { of } \\
\text { Variance }\end{array}$ & $\begin{array}{l}\% \text { of Cum. } \\
\text { Variance }\end{array}$ \\
\hline \multirow{3}{*}{ Curiosity } & (1) There are many things I want to know besides learning at university. & .811 & \multirow{3}{*}{2.608} & \multirow{3}{*}{23.708} & \multirow{3}{*}{23.708} \\
\hline & (2) Usually ask a lot of questions & .922 & & & \\
\hline & (3) I have a lot of questions about things that happen around me. & .856 & & & \\
\hline \multirow{3}{*}{$\begin{array}{l}\text { Task } \\
\text { commitment }\end{array}$} & (1) If don't know anything, research until know it. & .717 & \multirow{3}{*}{2.404} & \multirow{3}{*}{21.855} & \multirow{3}{*}{45.563} \\
\hline & (2) Doing everything meticulously. & .899 & & & \\
\hline & (3) When start concentrating, concentrate until the end. & .897 & & & \\
\hline \multirow{3}{*}{ Open mind } & (1) Admit fault honestly & .677 & \multirow{3}{*}{2.067} & \multirow{3}{*}{18.789} & \multirow{3}{*}{64.352} \\
\hline & (2) It is not difficult to think of someone else's position. & .793 & & & \\
\hline & (3) It's hard to accept a totally different idea from my thoughts & .886 & & & \\
\hline \multirow{2}{*}{$\begin{array}{l}\text { Aesthetic } \\
\text { impression }\end{array}$} & $\begin{array}{l}\text { (2) I am interested in various fields (art, science, culture, photography, } \\
\text { film, computer, foreign language, etc.) }\end{array}$ & .907 & \multirow[t]{2}{*}{1.844} & \multirow[t]{2}{*}{16.760} & \multirow[t]{2}{*}{81.112} \\
\hline & (3) Be well aware of artistic values & .930 & & & \\
\hline
\end{tabular}

Table 6. English Learning Effects Factor Analysis

\begin{tabular}{|c|c|c|c|c|c|}
\hline & & $\begin{array}{c}\text { Factor } \\
\text { Loading }\end{array}$ & $\begin{array}{l}\text { Eigen } \\
\text { Value }\end{array}$ & $\begin{array}{c}\% \text { of } \\
\text { Variance }\end{array}$ & $\begin{array}{c}\% \text { of Cum. } \\
\text { Variance }\end{array}$ \\
\hline \multirow{4}{*}{$\begin{array}{l}\text { Educational } \\
\text { interest }\end{array}$} & (4) I want to talk to a foreigner in English I learned in class & .884 & \multirow{4}{*}{3.848} & \multirow{4}{*}{25.652} & \multirow{4}{*}{25.652} \\
\hline & (5) I want to know how much I know English in class. & .856 & & & \\
\hline & (6) Always expect what I will learn in English class. & .862 & & & \\
\hline & (7) Enjoy English class. & .850 & & & \\
\hline \multirow{4}{*}{$\begin{array}{l}\text { Confidence of } \\
\text { learning }\end{array}$} & (1) English is easier than other subjects. & .689 & \multirow{4}{*}{3.478} & \multirow{4}{*}{23.188} & \multirow{4}{*}{48.839} \\
\hline & (3) Foreigners fully understand what I talking in English & .710 & & & \\
\hline & (4) My English pronunciation is good. & .892 & & & \\
\hline & (5) Can make a presentation in English without fear & .785 & & & \\
\hline \multirow{5}{*}{$\begin{array}{l}\text { English learning } \\
\text { usefulness }\end{array}$} & (1) English classes helped me to improve my english listening proficiency & .848 & \multirow{5}{*}{3.217} & \multirow{5}{*}{21.448} & \multirow{5}{*}{70.288} \\
\hline & (2) English classes helped me to improve my english speaking proficiency & 617 & & & \\
\hline & (3) English classes helped me to improve my english writing skill & .780 & & & \\
\hline & (4) English classes helped me to improve my english vocabulary proficiency & .787 & & & \\
\hline & (5) English classes helped me to improve my english grammar & .800 & & & \\
\hline \multirow{2}{*}{$\begin{array}{l}\text { English learning } \\
\text { suitability }\end{array}$} & (4) I plan to recommend English class to my friends & .749 & \multirow{2}{*}{1.888} & \multirow{2}{*}{12.585} & \multirow{2}{*}{82.873} \\
\hline & (5) I plan to re-participate in a program similar to this one. & .859 & & & \\
\hline
\end{tabular}


Table 7. Reliability of measurement variables.

\begin{tabular}{|c|c|c|c|c|c|c|c|c|c|}
\hline \multicolumn{2}{|c|}{ Entrepreneurship } & \multicolumn{2}{|c|}{ Self-efficacy } & \multicolumn{2}{|c|}{ Agricultural business } & \multicolumn{2}{|c|}{ Creative personality } & \multicolumn{2}{|c|}{$\begin{array}{l}\text { English educational } \\
\text { satisfaction }\end{array}$} \\
\hline Factors & Alpha & Factors & Alpha & Factors & Alpha & Factors & Alpha & Factors & Alpha \\
\hline Innovation & .860 & Self-confidence & .924 & $\begin{array}{l}\text { Entrepreneurial } \\
\text { intention }\end{array}$ & .954 & Curiosity & .878 & $\begin{array}{l}\text { Educational } \\
\text { interest }\end{array}$ & 952 \\
\hline Initiative & .907 & Self-control & .897 & $\begin{array}{c}\text { Type of } \\
\text { entrepreneurship }\end{array}$ & .969 & $\begin{array}{c}\text { Task } \\
\text { commitment }\end{array}$ & .862 & $\begin{array}{l}\text { Confidence } \\
\text { of learning }\end{array}$ & .907 \\
\hline $\begin{array}{l}\text { Risk } \\
\text { sensitivity }\end{array}$ & .830 & Task difficulty & .892 & & & Open mind & .752 & $\begin{array}{l}\text { English learning } \\
\text { usefulness }\end{array}$ & .880 \\
\hline Collaboration & .907 & & & & & $\begin{array}{l}\text { Aesthetic } \\
\text { impression }\end{array}$ & .860 & $\begin{array}{l}\text { English learning } \\
\text { suitability }\end{array}$ & .913 \\
\hline $\begin{array}{l}\text { Communication } \\
\text { skill }\end{array}$ & .927 & & & & & & & & \\
\hline $\begin{array}{l}\text { Networking } \\
\text { capabilities }\end{array}$ & .899 & & & & & & & & \\
\hline
\end{tabular}

self-efficacy was .892 or above, agro-entrepreneurial intention was .954 or above, creative personality was .752 or above, and English learning effects was .880 or above, all showing high reliability.

\section{Normality testing of variables}

Normality testing of variables was carried out because the research subjects are small samples.

Table 8 shows the result of One-Sample Kolmogorov-Smirnov Test. As a result of testing normality of variables in each group, collaboration in 6th industry entrepreneurship showed a departure from normality for the farming activity group, whereas for agro-entrepreneurship, there was a departure from normality in the type of cultural activity group participants. Most other variables did not show a departure from normality even though they were small samples, and thus analysis was conducted based on the assumption of normality. Accordingly, collaboration from 6th industry entrepreneurship factors departing from normality, and manufacturing, family-focused, distribution-focused tourism experience, functional, medicinal, healing-focused, agriculture-based, business diversified, industry association, and network connected businesses from agro-entrepreneurship types show a departure from normality, and therefore the analysis is applied through a nonparametric test.

\section{Perception gap between research groups about 6 th industry entrepreneurship}

Table 9 shows the perception gap between research groups about 6th industry entrepreneurship.

There was a perception gap in innovation, initiative, risk sensitivity, and communication skill among entrepreneurship. The perception level of farming activity participants was high for innovation $(\mathrm{t}=2.468, p<.05)$, initiative $(\mathrm{t}=2.171, p<.05)$, and risk sensitivity $(\mathrm{t}=2.713, p<.05)$, and that of cultural activity participants was high for communication skill ( $\mathrm{t}=-3.190$, $p<.05)$. It turned out there was no perception gap between research groups in terms of collaboration and networking capabilities. 


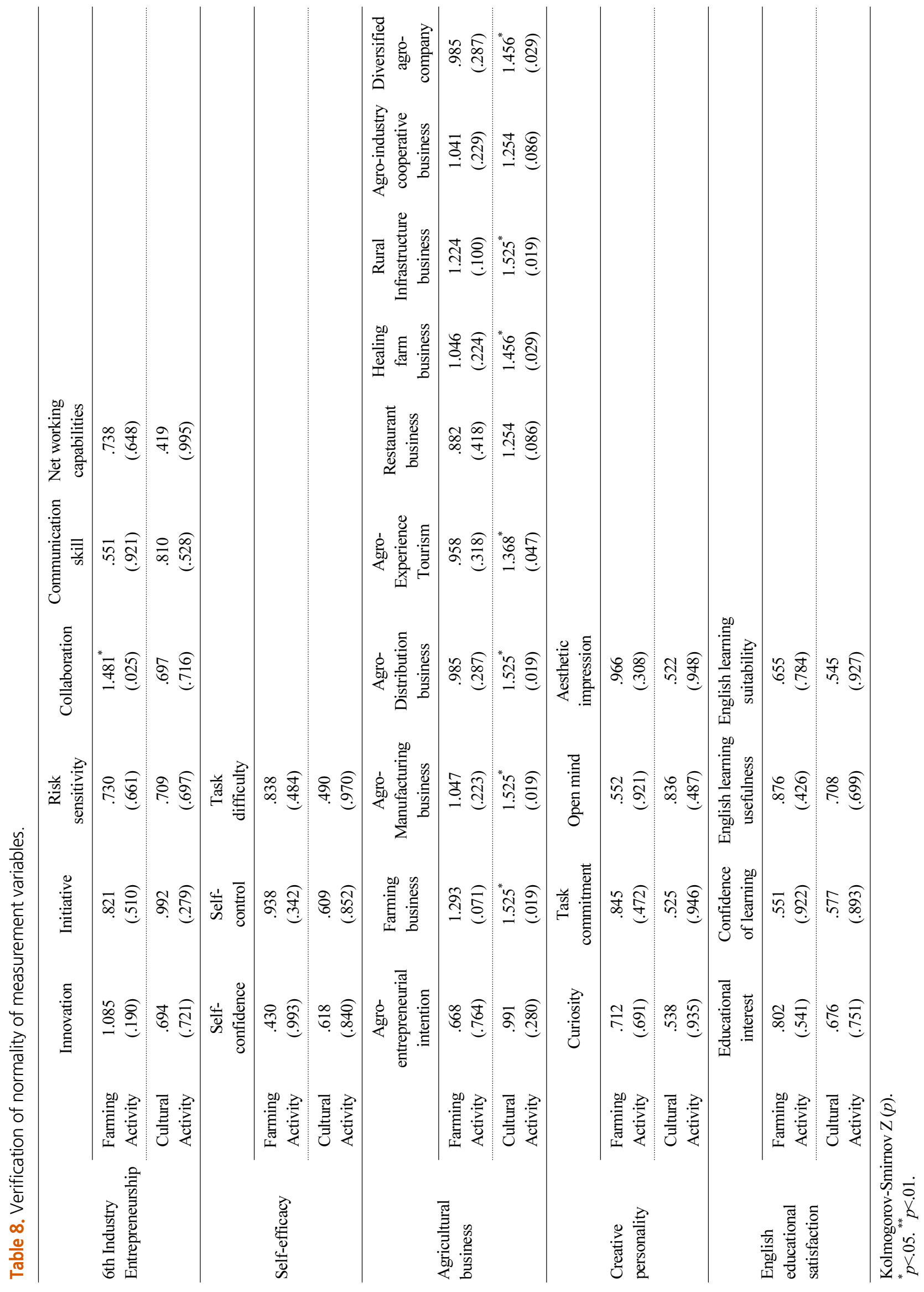


Table 9. Comparison of participants' perception of each program on 6th Industry Entrepreneurship.

\begin{tabular}{lcccccc}
\hline & Innovation & Initiative & Risk sensitivity & Collaboration & Communication skill & Networking capabilities \\
\hline Farming activity & $3.60 \pm 0.69$ & $3.43 \pm 0.85$ & $3.24 \pm 0.76$ & $3.82 \pm 0.64$ & $3.73 \pm 0.76$ & $3.26 \pm 0.42$ \\
Cultural activity & $3.17 \pm 0.82$ & $3.03 \pm 0.73$ & $2.77 \pm 0.74$ & $3.85 \pm 0.75$ & $4.26 \pm 0.65$ & $3.52 \pm 0.99$ \\
$\mathrm{t}(p)$ & $2.468^{*}(.016)$ & $2.171^{*}(.033)$ & $2.713^{* *}(.008)$ & $\mathrm{Z}=-563(.574)$ & $-3.190^{* *}(.002)$ & $-1.418(.165)$ \\
\hline
\end{tabular}

Values are presented mean \pm standard deviation.

$\mathrm{Z}$ : Mann-Whitney U test.

${ }^{*} p<.05 .{ }^{* *} p<.01$.

\section{Perception gap between research groups about self-efficacy}

Table 10 shows the perception gap between research groups about self-efficacy.

There was a perception gap between research groups in self-control among self-efficiency $(\mathrm{t}=-4.414, p<.001)$. The perception level of cultural activity participants was high, whereas there was no perception gap between research groups in terms of self-confidence and task difficulty.

\section{Perception gap between research groups about agro-entrepreneurial intention}

Table 11 shows the perception gap between research groups about agro-entrepreneurial intention.

There was a perception gap between research groups in all variables of agro-entrepreneurial intention. The perception

Table 10. Comparison of participants' perception of each program on Self-efficacy.

\begin{tabular}{lccc}
\hline & Self-confidence & Self-control & Task difficulty \\
\hline Farming activity & $2.40 \pm 0.85$ & $3.21 \pm 0.51$ & $2.52 \pm 0.77$ \\
Cultural activity & $2.57 \pm 0.78$ & $3.82 \pm 0.65$ & $2.88 \pm 0.97$ \\
$\mathrm{t}(p)$ & $-.825(.412)$ & $-4.414^{* * *}(.000)$ & $-1.739(.086)$ \\
\hline
\end{tabular}

Values are presented mean \pm standard deviation.

${ }^{* * *} p<.001$.

Table 11. Comparison of participants' perception of each program on Agro-entrepreneurial intention.

\begin{tabular}{|c|c|c|c|c|c|c|c|c|c|c|}
\hline & \multirow[b]{2}{*}{$\begin{array}{l}\text { Agro- } \\
\text { entrepreneurial } \\
\text { intention }\end{array}$} & \multicolumn{9}{|c|}{ Types of agricultural entrepreneurship } \\
\hline & & $\begin{array}{c}\text { Agro- } \\
\text { Cultivating } \\
\text { business }\end{array}$ & $\begin{array}{c}\text { Agro- } \\
\text { Manufacturing } \\
\text { business }\end{array}$ & $\begin{array}{c}\text { Agro- } \\
\text { Distribution } \\
\text { business }\end{array}$ & $\begin{array}{l}\text { Agro- } \\
\text { Experience } \\
\text { Tourism }\end{array}$ & $\begin{array}{c}\text { Restaurant } \\
\text { business }\end{array}$ & $\begin{array}{l}\text { Healing } \\
\text { farming } \\
\text { business }\end{array}$ & $\begin{array}{c}\text { Rural } \\
\text { Infrastructure } \\
\text { business }\end{array}$ & $\begin{array}{l}\text { Agro- } \\
\text { industry } \\
\text { cooperative } \\
\text { business }\end{array}$ & $\begin{array}{l}\text { Diversified } \\
\text { agro- } \\
\text { company }\end{array}$ \\
\hline $\begin{array}{l}\text { Farming } \\
\text { activity }\end{array}$ & $2.66 \pm 1.14$ & $3.14 \pm 0.93$ & $3.14 \pm 0.84$ & $3.21 \pm 0.68$ & $3.71 \pm 0.97$ & $3.64 \pm 0.82$ & $4.00 \pm 0.94$ & $3.64 \pm 0.73$ & $3.71 \pm 0.81$ & $3.79 \pm 0.68$ \\
\hline $\begin{array}{l}\text { Cultural } \\
\text { activity }\end{array}$ & $1.34 \pm 0.58$ & $1.20 \pm 0.41$ & $1.20 \pm 0.41$ & $1.20 \pm 0.41$ & $1.30 \pm 0.47$ & $1.50 \pm 0.94$ & $1.40 \pm 0.93$ & $1.20 \pm 0.41$ & $1.50 \pm 0.94$ & $1.40 \pm 0.93$ \\
\hline $\mathrm{t}(p)$ & $\begin{array}{c}6.402^{* * *} \\
(.000)\end{array}$ & $\begin{array}{c}Z=-7.195^{* * *} \\
(.000)\end{array}$ & $\begin{array}{c}\mathrm{Z}=-7.153^{* * *} \\
(.000)\end{array}$ & $\begin{array}{c}\mathrm{Z}=-7.270^{* * *} \\
(.000)\end{array}$ & $\begin{array}{c}\mathrm{Z}=-7.078^{* * *} \\
(.000)\end{array}$ & $\begin{array}{c}10.288^{* * *} \\
(.000)\end{array}$ & $\begin{array}{c}\mathrm{Z}=-6.716^{* * *} \\
(.000)\end{array}$ & $\begin{array}{c}\mathrm{Z}=-7.397^{* * *} \\
(.000)\end{array}$ & $\begin{array}{c}10.740^{* * *} \\
(.000)\end{array}$ & $\begin{array}{c}\mathrm{Z}=-6.604^{* * *} \\
(.000)\end{array}$ \\
\hline
\end{tabular}

Values are presented mean \pm standard deviation.

Z: Mann-Whitney U test.

${ }^{* * *} p<.001$. 
level of farming activity participants was high, whereas cultural activity participants showed no agro-entrepreneurial intention at all.

\section{Perception gap between research groups about creative personality}

Table 12 shows the perception gap between research groups about creative personality.

There was a perception gap between research groups in task commitment among creative personality. The perception level of cultural activity participants was high, whereas there was no perception gap between research groups in terms of curiosity, open mind, and aesthetic impression.

\section{Perception gap between research groups about English learning effects}

Table 13 shows the perception gap between research groups about English learning effects.

There was a perception gap between research groups in confidence of learning and English learning suitability among English learning effects. The perception level of cultural activity participants was high, whereas there was no perception gap between research groups in terms of educational interest and English learning usefulness.

\section{Effects of English activities and related variables on agro-entrepreneurial intention}

Two methods were used to determine the results of the multiple regression analysis on agro-entrepreneurial intention.

First, demographic characteristics are controlled to determine the effects on overall agro-entrepreneurial intention, and 6th industry entrepreneurship (innovation, initiative, risk sensitivity, collaboration, communication skill, networking capabilities), self-efficacy (self-confidence, self-control, task difficulty), creative personality (curiosity, task commitment, open mind, aesthetic impression), English learning effects(educational interest, confidence of learning, English learning usefulness, English learning suitability) were included as independent variables. Only variables with statistically significant effects were extracted through stepwise regression analysis (Table 14). Second, the same method was used to determine

Table 12. Comparison of participants' perception of each program on Creative personality.

\begin{tabular}{lcccc}
\hline & Curiosity & Task commitment & Open mind & Aesthetic impression \\
\hline Farming activity & $3.93 \pm 0.60$ & $3.36 \pm 0.76$ & $3.88 \pm 0.76$ & $3.96 \pm 1.07$ \\
Cultural activity & $4.10 \pm 0.91$ & $4.07 \pm 0.76$ & $3.87 \pm 0.71$ & $3.65 \pm 0.88$ \\
$\mathrm{t}(p)$ & $-.963(.339)$ & $-3.918^{* * *}(.000)$ & $.081(.936)$ & $1.317(.192)$ \\
\hline
\end{tabular}

Values are presented mean \pm standard deviation.

${ }^{* * *} p<.001$.

Table 13. Comparison of participants' perception of each program on English education.

\begin{tabular}{lcccc}
\hline & Educational interest & Confidence of learning & English learning usefulness & English learning suitability \\
\hline Farming activity & $4.00 \pm 0.58$ & $2.71 \pm 0.65$ & $4.10 \pm 0.76$ & $3.75 \pm 0.81$ \\
Cultural activity & $4.30 \pm 0.77$ & $3.45 \pm 1.10$ & $4.04 \pm 0.65$ & $4.15 \pm 0.76$ \\
$\mathrm{t}(\mathrm{p})$ & $-1.799(.078)$ & $-3.277^{* *}(.002)$ & $.352(.726)$ & $-2.130^{*}(.037)$ \\
\hline
\end{tabular}

Values are presented mean \pm standard deviation.

${ }^{*} p<.05 .{ }^{* *} p<.01$. 
Table 14. Multiple regression analysis of English learning effects and related variables on agro-entrepreneurial intention.

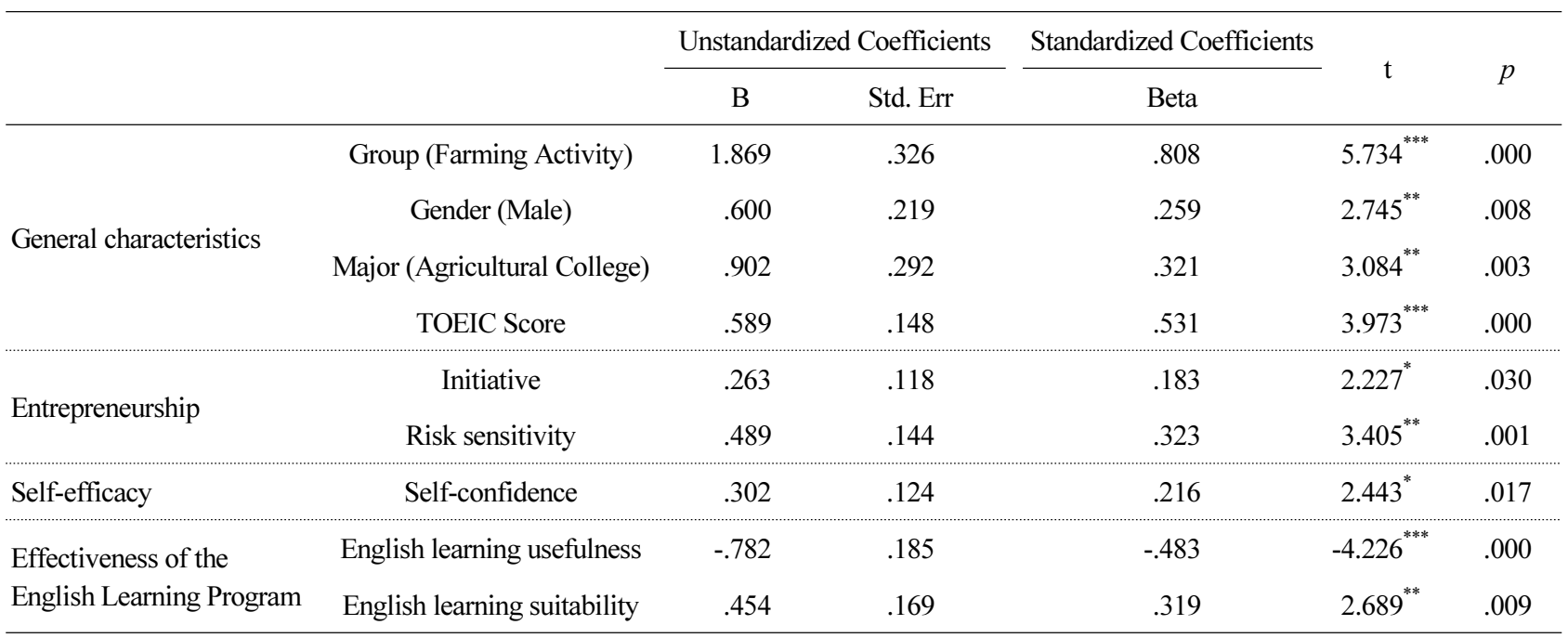

$\mathrm{R}^{2}=.684$, Adj. $\mathrm{R}^{2}=.639, \mathrm{~F}=14.939, p=.000, \mathrm{VIF}=1.531 \sim 3.902$.

${ }^{*} p<.05 .{ }^{* *} p<.01 .{ }^{* * *} p<.001$.

the effects of each variable on the agro-entrepreneurial intention by type through stepwise regression analysis (Table 15).

First of all, overall agro-entrepreneurial intention turned out to be high among those who participated in farming activity program among demographic variables $(\beta=.808)$, men $(\beta=.259)$, students in agriculture-related departments $(\beta$ $=.321$ ), and those with higher TOEIC scores $(\beta=.531)$. Furthermore, agro-entrepreneurial intention was higher when initiative $(\beta=.183)$ and risk sensitivity $(\beta=.323)$ were higher among 6th industry entrepreneurship. As for self-efficacy, self-confidence ( $\beta=.216$ ) turned out to be the most important influential factor. In addition, for English earning effects, those with low English learning usefulness $(\beta=-.483)$, and those with high English learning suitability $(\beta=.319)$ had stronger agro-entrepreneurial intention.

The explanatory power of this model is $63.9 \%$, and the regression model is statistically significant $(\mathrm{F}=14.939, p<.001)$

\section{Effects of English activities and related variables on agro-entrepreneurial types}

Next, the following shows the factors that affect agro-entrepreneurial intention by 9 types.

For manufacturing business, those participating in farming activity $(\beta=.995)$, men $(\beta=.173)$, those with higher TOEIC scores $(\beta=.414)$ and higher intention, those with higher risk sensitivity $(\beta=.258)$ and lower communication skill $(\beta=-.191)$ among 6th industry entrepreneurship were more likely to start manufacturing business.

For processing business, those participating in farming activity $(\beta=1.593)$, men $(\beta=.543)$, those with higher TOEIC scores $(\beta=.945)$, not farmers in succession $(\beta=-.129)$, have higher entrepreneurial intention, and lower innovation $(\beta$ $=-.279)$ as well as higher initiative $(\beta=.163)$ and risk sensitivity $(\beta=.388)$ among 6th industry entrepreneurship were more likely to start processing business. Moreover, those with higher self-confidence ( $\beta=.333)$ and self-control $(\beta=.400)$ among self-control, those with lower curiosity $(\beta=-.346)$ and open mind $(\beta=-.141)$ and higher aesthetic impression $(\beta=.363)$ among creative personality had higher intention to start processing business, along with those who have higher educational interest $(\beta=.423)$ and lower confidence of learning $(\beta=-.389)$ among English learning effects.

For distribution business, those participating in farming activity $(\beta=1.227)$, men $(\beta=.350)$, those in younger age $(\beta$ $=-.106)$, are students in agriculture-related departments $(\beta=.160)$, have experience studying abroad $(\beta=.066)$, and have 


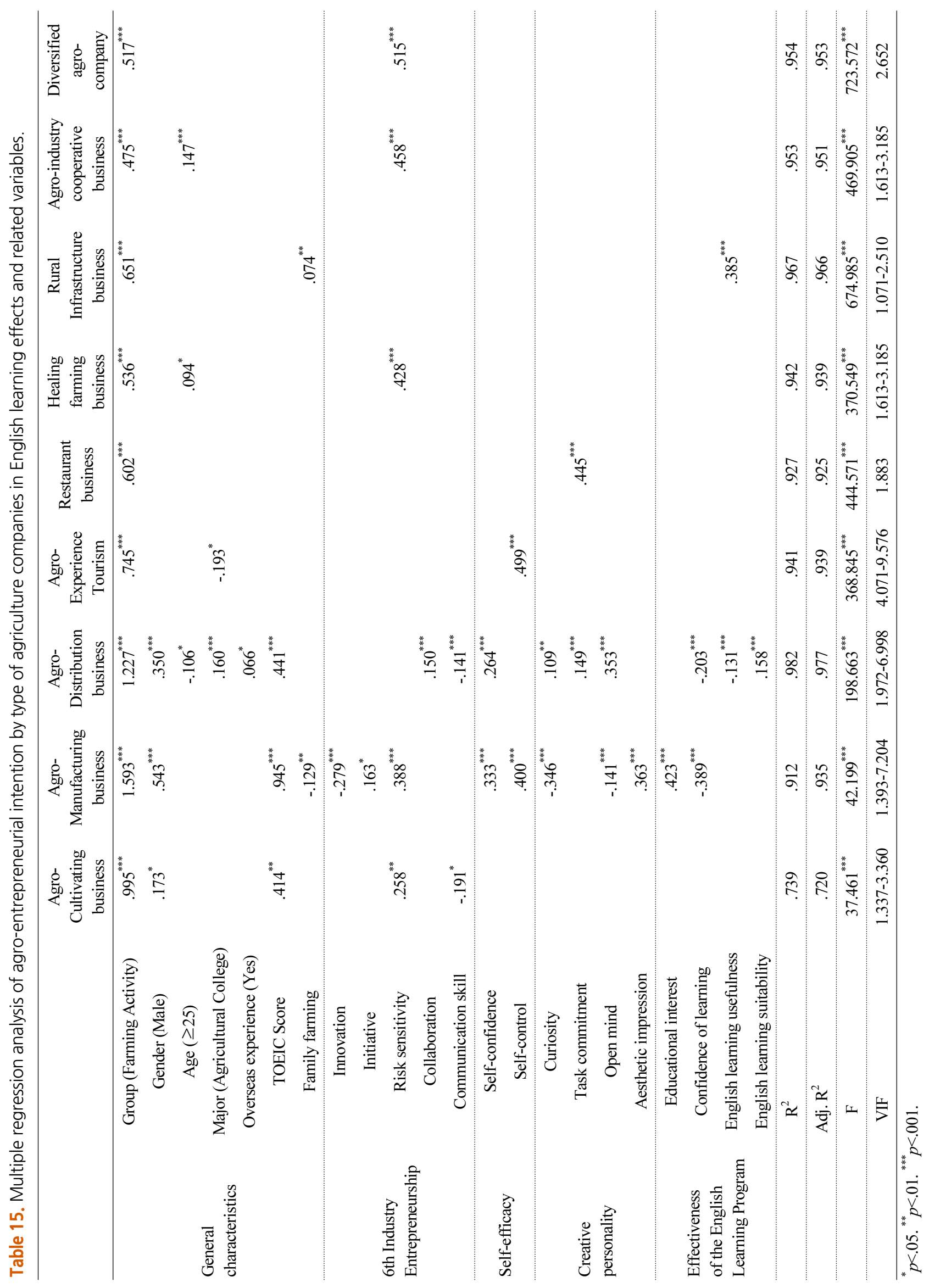


higher TOEIC scores $(\beta=.441)$ show higher intention. Those with higher collaboration $(\beta=.150)$ and lower communication skill $(\beta=-.141)$ among 6th industry entrepreneurship were likely to start business in distribution. Those with higher self-confidence ( $\beta=.264$ ) among self-control and higher curiosity ( $\beta=.109)$, task commitment ( $\beta=.149)$, and open mind ( $\beta$ $=.353$ ) among creative personality had higher intention to start business in distribution. Those with lower confidence of learning $(\beta=-.203)$ and English learning usefulness $(\beta=-.131)$ and higher English learning suitability $(\beta=.158)$ among English learning effects showed higher intention.

For tourism using agricultural products, those participating in farming activity $(\beta=.745)$ and not students in agriculturerelated departments $(\beta=-.193)$ showed higher intention. Those with higher self-control $(\beta=.499)$ also showed higher intention.

For restaurant business, those participating in farming activity $(\beta=602)$ showed higher intention, and those with higher task commitment ( $\beta=.445$ ) among creative personality also showed higher intention to start restaurant business using agricultural products.

For healing farming business using the functional and medicinal effects of agricultural products, those participating in farming activity $(\beta=.536)$ and are in older age $(\beta=.094)$ showed higher intention to start business, and those with higher risk sensitivity $(\beta=.428)$ among 6 th industry entrepreneurship also showed higher intention.

For diverse agriculture-based businesses aside from manufacturing led by farmers, those participating in farming activity $(\beta=.651)$ and farmers in succession $(\beta=.074)$ had higher intention, and those with high usefulness among English learning effects $(\beta=.385)$ showed higher intention to start diverse agriculture-based businesses.

For processing and service business based on agriculture in which agricultural production is specialized by farmers, the intention to start the business in collaboration with related businesses was higher for those participating in farming activity ( $\beta=.475)$ and are in older age $(\beta=.147)$. Those with higher risk sensitivity $(\beta=.458)$ among 6th industry entrepreneurship also showed higher intention.

For business with simultaneous connectivity between business diversification industry-affiliated networking of farmers, those participating in farming activity $(\beta=.517)$ had higher intention. Those with higher risk sensitivity $(\beta=.515)$ among 6th industry entrepreneurship showed higher intention in starting business about specialized manufacturing by farmers and processing and service business based on agriculture is carried out in collaboration with businesses.

\section{Conclusion}

The results of comparing agro-entrepreneurial intention of students participating in the overseas language training during winter holidays in G region of the US are as follows. By program, the agro-entrepreneurial intention was significantly higher for participants of English-farming activity program than English- cultural activity program, male than female students, agriculture department students, and higher TOEIC scores. In terms of English learning effects, those with low usefulness and high suitability had stronger agro-entrepreneurial intention. Those with higher initiative and risk sensitivity for entrepreneurship and higher self-confidence for self-efficacy showed higher agro-entrepreneurial intention.

By type of business, participants of English-farming activity program showed higher significance than participants of English-cultural activity program in all categories. Among them, interest in agricultural processing and distribution was especially high. As for 6th industry entrepreneurship focused on processing, students with higher aesthetic impression for creative personality showed higher intention. As for 6th industry entrepreneurship focused on distribution, students with higher collaboration in entrepreneurship and open mind in creative personality showed higher intention. For 6th industry entrepreneurship focused on tourism, students in non-agriculture departments for major and those with higher self-control 
in terms of self-efficacy showed higher intention. As for 6th industry entrepreneurship focused on restaurants, those with higher task commitment in terms of creative personality showed higher intention. For collaboration and healing, those in older age who have higher risk sensitivity showed higher intention. For 6th industry entrepreneurship based on agriculture, farmers in succession had higher intention to start up, whereas for that based on networking, those with higher risk sensitivity showed higher intention. As a result of running an integrated program of short-term job program and English learning specialized in students in agriculture-related departments, it was found that motivation for English learning and career goals became more specific, thereby exerting a positive effect on career awareness.

\section{References}

Bang, G.H. 2015. A study on recent trends of general agricultural education in the United States. J. Korean Pract. Arts Educ. 28(3):39-55.

Chung, N.Y. 2004. Trend and fostering strategies for agricultural literacy education in higher education institutes. J. Agric. Educ. Hum. Resour. Dev. 36(4):21-35.

DuRivage, M. 2011. Cultivating knowledge in the school garden: new ways of teaching literacy to ESL students. MA TESOL Collection. SIT Graduate Institute. Retrieved from http://digitalcollections.sit.edu/ipp_collection/495/

Jeong, S.J., M.I. Jeong, Y.J. Song, J.S. Kim, J.M. Rho, J.W. Lee, J. H. Moon, and W.S. Kim. 2010. Effect of horticulturekorean language integrated program of special aptitude class after school on the learning Interest, learning accomplishment related to Korean language and plant-familiarity for elementary school student. J. Korean Soc. People Plants Environ. 13(5):1-7.

Kim, M.J. 2006. A study on the career awareness of elementary schoolers. MS thesis, Kwandong Univ., Gangneung-si, Korea.

Kim, S.K., H.S. Park, J.S. Park, S.B. Moon, and E.I. Son. 2016. Development of index about the sixth industrial entrepreneurship. Asia-Pac. J. Bus. Ventur. Entrep. 11(3):63-76.

Kwack, H.R., E.J. Jang, and B.R. Suh. 2012. Study for the development of USA's Texas junior master gardener program and horticultural activities for elementary horticultural education. J. Korean Soc. People Plants Environ. 15(2):135-147.

Lynn, O. and E. Pranis. 1983. The youth gardening book: a complete guide for teachers, parents and youth leaders. National Gardening Association. Gardens for All, Inc., Burlington, USA.

Noguchi, T., K.Yoshikawa, and M. Nakamura. 2008. Overseas internship education in engineering graduate courses and evaluation of the educational effect. J. Jpn. Soc. Eng. Educ. 56(3):80-85. DOI: 10.4307/jsee.56.3_80

Park, C.S. 2009. A study on the effect of overseas language training programs upon the transition from college to labor market. J. Employ. Skills Dev. 12(1):117-139.

Yang, E.M. 2015. Korean college students' L2 learning experience in a short-term study abroad context: a grounded theory approach. J. Korea Engl. Educ. Soc. 14(1):103-134.

Yi, P. 2016. Time to degree of four-year university students in Korea. J. Educ. Adm. 34(5):223-246.

Yoon, Y.S. 2011. The Effects of Short-term Study Abroad on Self-regulated Learning Ability and Satisfaction. MS thesis, Chungnam Natl. Univ., Daejeon, Korea. 